H A R VAR D B US I NES S S C H O O L

\title{
Business and Sustainability: New Business History Perspectives
}

Ann-Kristin Bergquist

Working Paper 18-034 


\title{
Business and Sustainability: New Business History Perspectives
}

\author{
Ann-Kristin Bergquist
}

Harvard Business School

Working Paper 18-034 


\title{
Business and Sustainability: New Business History Perspectives
}

\section{Ann-Kristin Bergquist}

\begin{abstract}
:
This working paper provides a long-term business history perspective on sustainability. For a long time, the central issues in business history concerned how business enterprises innovated and created wealth, and patterns of success and failure in that process. There now exists, after a lag, a compelling stream of research focused on the environmental consequences of that growth. This working paper reviews this new stream of research which focuses on two related but distinct themes. The earliest theme to be explored, in a literature dating from the $1990 \mathrm{~s}$, is the story of how and why some conventional industries sought to become less polluting. Research has dated this phenomenon back to the late nineteenth century, showed it gained momentum from the 1960s, and resulted in a mainstreaming of sustainability rhetoric , and sometimes practice, in large corporations from 1980s, primarily in Western developed countries. A more recent research theme is the story of how for-profit entrepreneurs developed new product categories such as organic food, and wind and solar energy, which were explicitly focused on sustainability. Again this process has been traced back to the nineteenth century. With the rise in green consumerism and public policy support in some Western countries for sustainability during the 1990 s, these two historical trends met, as the concept of sustainable development spread to large conventional corporations and visionary green firms scaled or were acquired by conventional big businesses. The problem was that concept of sustainability became socially constructed in a sufficiently broad fashion as to permit even the most unstainable and dirty industries to firms claim to be sustainable. The working paper concludes that the emergent business history needs to be more fully incorporated in wider management and economics literatures on sustainability, while calling for the mainstreaming of the subject in the discipline of business history.
\end{abstract}




\section{Business and Sustainability: New Business History Perspectives}

\section{Ann-Kristin Bergquist}

\section{Introduction}

This working paper provides a long-term business history perspective on sustainability. The twentieth century is unique in history, not only because its enormous technological progress and rise in the standard of living, but because that no other century in human history can be compared with the twentieth century for its growth in energy use, depletion of natural resources and an overall growth of problems related to global environmental sustainability (McNeill, 2000; the United Nations; 2016). ${ }^{1}$ It has often been asserted that industrial capitalism, globalization and multinational companies have been central actors in this development (Wright \& Nyberg, 2015).

Business historians have shown how business has driven economic growth since the Industrial Revolution. Business historians have shown how firms, especially large manufacturing ones, contributed to commercialization of new products and processes which embodied innovative technologies that critically impacted the world economy from the nineteenth century (Chandler et. al 1997: Jones \& Zeitlin, 2008). It could be provocatively suggested that business historians have, therefore, documented how business made the world unsustainable. The creation of modern capitalism was essentially the story of manufacturing firms growing large by employing enormous amounts of fossil fuels: the railroad industry; the oil industry; the electric industry, the chemical industry, the car industry and others. Fossil fuels and natural resource depletion have been crucial components of both the past two centuries of economic expansion, and of today's current environmental crisis.

\footnotetext{
${ }^{1}$ In 2016 the United Nations presented their most authoritative study ever published-the Global Environmental Outlook (GEO-6): Regional Assessments report-on the state of the planet's health, which concluded that environment is deteriorating even faster than previously thought.
} 
Is often assumed among scholars and business practitioners that business challenges related to sustainability is a recent phenomenon. But as business and environmental historians have increasingly shown, ideas and concerns about pollution and nature conservation date back to the nineteenth century. A handful of entrepreneurs even then began thinking that pollution prevention, recycling, renewable energy and providing healthy food were their responsibilities (Rosen, 1995; Jones, 2017a; Berghoff \& Rome, 2017: Bergquist \& Lindmark, 2016). Incipient steps towards pollution control and creation of green businesses was taken as a first reaction towards industrialization in the late nineteenth and early twentieth century, but a much broader and more forceful social movement only emerged in the 1960s. The environmental awaking in the late 1960s mobilized mass movement, a development of new institutions, including a complex of laws and organizational bodies to protect the environment (Brenton, 1994: Jones 2017a). Harsh critique against the business community was coupled with this environmental awakening, initially in the United States (Carrol et al. 2012; Rome, 2017). Environmental regulation emerged as a serious challenge in polluting industries, with operations based in Western countries (Coglianese \& Andersson, 2012; Bergquist, 2017; Gunningham et al. 2003).

From the 1960s and the 1970s the issue of business and the environment grew to become broader and more complex. The Brundtland report in 1987 brought environmental issues into the concept of sustainable development paraphrased as: "meeting the needs of the present generation without comprising the ability for future generations to meet their own needs" (WCED, 1987). Translated into a business context, this implied that business could no longer regard the environment as limitless pool of natural capital that could be drawn down upon without liability (Blowfield, 2013:6). In the 2000s, the "greening" label started to morph into "sustainability" and sustainability became translated into business language, such as the "triple bottom line" and eco-efficiency and became diffused into virtually every major 
corporation in the developed world (Ehrenfeld, 2012; Jones, 2017a). The issue of business and the environment also received an increased attention in academic research from the mid-1980s, including the field of business administration. The development is mirrored in The Oxford Handbook of Business and the Natural Environment (Bansal \& Hoffman, 2012), which included thirty-eight overview chapters of different subfields in business strategy, organizational theory, marketing, accounting, international business, finance and other fields.

Business history was for a long time silent about the topic with only a handful of scholars engaged in it. A first call to integrate the natural environment in business history was made in a special issue in Business History Review in 1999 (Rosen \& Sellers, 1999). In 2011, the editors of the same journal noticed that business historians had still devoted surprisingly little attention to the environment, and called for an incorporation of sustainability in mainstream business history (Friedman \& Jones, 2011). The earliest theme in business historical research, dating in the 1990s, was focused on how business and governments had responded to industrial pollution problems in the nineteenth and the first part of the twentieth century (e.g. Rosen \& Sellers, 1999; Rosen, 1995; Rosen, 2003; Ueköetter, 1999). Since then, there has been an expansion of research that has covered the period after the 1960s (e.g. Jones, 2017a; Jones, 2018; Rome \& Berghoff, 2017; Boulett, 2006; Lindmark \& Bergquist, 2009; Sluyterman, 2010; Bergquist \& Söderholm, 2015; 2011; Jones \& Lubinski, 2014; Blackford, 2013; Müller, 2017, Aggeri \& Cartel, 2017). Existing research do not cover all industries and all different time periods, why the coverage of the literature in this chapter is mainly centered on the Western world. The chapter begins with overviewing the current debate of sustainability and its historical roots, before turning to how business has responded to this challenge over time. 


\section{Business and Sustainability: Defining the Challenge}

The issue of sustainability is deeply rooted in the Industrial Revolution. Firms and industries have for centuries taken advantage of natural resources to fill their needs for energy and raw materials. Before the Industrial Revolution however, the pre-modern growth conditions were constrained by ecological factors (Pomeranz, 2000; Clark, 2007). The post-industrial growth was situated in an organic energy regime, based on human and animal muscle power for mechanical power and on wood and other biomass for heat (McNeill, 2000). With the Industrial Revolution, the pre-modern growth restrictions were crossed when coal replaced firewood and charcoal. The key technology that brought coal into the energy system was the steam engine, which laid the foundation for intensified industrialization, the growth of large firms and exponential economic growth based on fossil fuels.

Core inventions of the Second Industrial Revolution such as electricity, the combustion engine, advances in the chemical industry spurred an economic growth driven by the expansion of big business (Chandler et al. 1997). But this also urged forward further environmental degradations, which from the 1950s begun to accelerate tremendously (McNeill \& Engelke, 2014). Many natural scientists have suggested that our planet has entered a new geological age, the so-called Anthropocene, as an effect of accumulated human economic activity (Steffen et al. 2015). The previous age, the Holocene begun 10,000 to 12,000 years ago, when the climate became warmer and much more stable. It is argued that the Anthropocene begins around 1800 with the onset of industrialization, with rapid expansion in the use of fossil fuels being its central feature (Steffen et al. 2007). The 1950s thus marks the beginning of the second stage of the Anthropocene - a stage that has been coined as the Great Acceleration. The Anthropocene and Great Acceleration debate essentially draws attention to the explosion of population growth and an unsustainable and exponential energy use after 1945 and its negative impact on Earth system, most critically climate change and the rate of biodiversity loss (Whiteman et al. 2013; Steffen 
et al. 2015). Fossil fuel based capitalism, with its deep roots in the nineteenth and twentieth century, are integrated with this debate (McNeill \& Engelke, 2014). The historical development of $\mathrm{CO}_{2}$ emissions is illustrated in Figure 1, and demonstrates the acceleration of these emissions since the 1950s.

Figure 1. Carbon Dioxide Emissions from Fossil Fuels 1751-2007

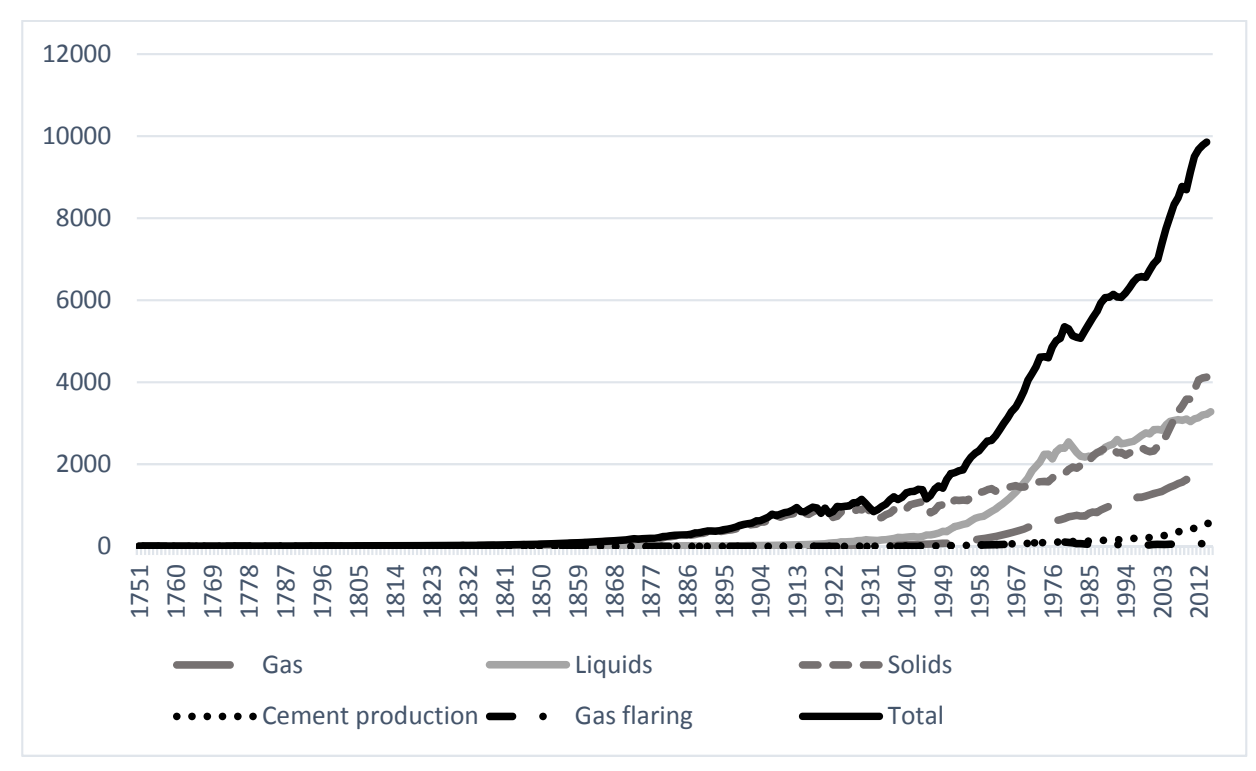

Source: oden, T.A., G. Marland, and R.J. Andres. 2017. Global, Regional, and National FossilFuel CO2 Emissions. Carbon Dioxide Information Analysis Center, Oak Ridge National Laboratory, U.S. Department of Energy, Oak Ridge, Tenn., U.S .A http://cdiac.ornl.gov/ftp/ndp030/global.1751 2014.ems

The concept of sustainable development has been abundantly debated, and unlike climate change, sustainability and sustainable development did not emerge as a scientific concept (Cohen et al. 1998; Robinson, 2004). In research, the concept of corporate sustainability is still developing (Whiteman et al. 2013). The business historian Geoffrey Jones has recently shown, that sustainability should be understood as a concept that has been socially and politically constructed, also by business, and has reflected the interests and values of those entrepreneurs, social groups and organizations being involved (Jones, 2017a). For instance, when sustainable 
development became widely translated into business strategies in the 1990s, one critical issue emerged about how to 'measure' sustainability, how to evaluate and claim that a business practice or a product is 'green' and what criteria that should be used to weigh such claims (Jones, 2017a; Robinson, 2004). Corporate practices in responding to the sustainability challenge, again with climate change as its central issue, involves an understanding of how business have captured and constructed the concept.

\section{Business and the First Wave of Environmentalism}

Seen in a long term perspective, the reaction towards the environmental destruction caused industrial growth came in two waves (Guha, 1999; Weber \& Soderstrom, 2012; Jones, 2017a). A first wave of environmentalism occurred in the nineteenth century, which came to proceed step-by-step with the Industrial Revolution up until the 1930s. It included anti-pollution movements and the first local anti-pollution legislations in the United States and Western Europe, along with a growing nature conservation movement, which, among other things, triggered the establishment of national parks (Jones, 2017a). The initiatives were at first isolated and sporadic, but gained force as the nineteenth century ended and the evils of polluted cities, industries and impoverished communities generated a fledging social movements in the United States (Post, 2012:542) but also in Europe (Rootes, 2004). A second wave of environmentalism emerged in 1960s but had other characteristics than the first wave. Besides turning into a mass movement, the second wave was based on a dramatic expansion of science and rational models of knowledge about nature as well as the emergence of an anti-establishment and politically left-leaning critique of capitalism after World War II. The first wave was primary a cultural movement with limited mass mobilization and protest capacity to stop the course of industrialization (Weber \& Soderstrom, 2012).

Research looking at the forceful impact on the natural environment caused by the 
industrial capitalism was first driven by environmental historians (Worster, 1979; Cronon, 1991). The seminal work of Worster (1979) delivered a harsh critique against capitalism, which became formative for the subject (Rome, 2017). The one-sided perception of business and capitalism as a dark destructive force turned out to be more complicated and diverse when business historians like Christine Meisner Rosen began to take a closer look into processes "inside" the business community. She demonstrated how business in the late nineteenth century responded with great variety to controlling smoke in industrializing American cities, where some businessmen voluntary committed themselves to smoke abatement and supported regulation, while some actors were engaged themselves in organized resistance to impose controls (Rosen, 1995). The importance of awareness of the variety of business responses among individual entrepreneurs, managers, industries and countries were stressed by Christine Meisner Rosen and Christopher Sellers (1999) when they argued for an "ecocultural" history of business.

\section{Manufacturing Industries}

Technological inventions, such as steam power, and later the electricity and the combustion engine, formed clusters of innovations that not only enabled business corporations to utilize an enormous amount of fossil fuels, metals and wood fibers in production, but also possibilities for firms to grow very large (Chandler, 1990). Along with the rise of modern science, fossil fuel enabled massive increases in productivity through the spread of factory production and economies of scale and scope. This in turn drove global commerce (Jones, 2008), but also environmental degradation to an extent that the world had not experienced before (McNeill, 2000).

The breakthrough of industrial capitalism and the first wave of globalization thus gave rise to very serious negative externalities and organized local protests, conflicts and even 
governmental interventions emerged in more seriously damaged areas. One battle was played out in industrial cities, concerning issues around coal smoke (Uekötter, 2009; Rosen, 1995) and another battle emerged in mining and metals smelting districts, essentially around copper smelters, who even by the standards of the industrial revolution were notorious for its extremely noxious smoke. Smoke damages caused copper smelting increased as the global demand for copper skyrocket in the 1880s, especially in the United States (MacMillan (2000; Maysilles; 2011; LeCain; 2000, 2009) while the damages in Europe was concentrated to the Swansea district in Wales, Great Britain (Newell, 2009). The challenge to find technological solutions to air pollution problems emerged across different copper companies in the United States, who dealt with the issue under conflicts and pressure. Donald MacMillan (2000) demonstrated in his book Smoke Wars: Anaconda Copper, Montana Air Pollution, and the Courts, 1890-1924 how the battle against the Anaconda Company even caused the US president Theodore Roosevelt to intervene in the 1910s. Considerable improvements of abatement technologies in metals smelting were accomplished in the early twentieth century. The most important innovation was the so called electric precipitator, an electric filter, which captured pollutants including sulfur and arsenic in the smoke with up to 90 percent (LeCain, 2009). Knowledge and learning about the environmental disasters in the United States, as well as abatement technologies advanced there, diffused to Europe through global business networks (Bergquist \& Lindmark, 2016).

The copper companies understood that the sulfur released through the smoke stacks did not only destroy the environment, but was also represented potentially profitable sulfur and arsenic products going to waste. When more efficient abatement technology was developed in the metal industry in early twentieth century, it was a technology that enabled the extraction of metallic dust from smelter smoke, which could be transformed into profitable by products (LeCain, 2000). In the first decades of the twentieth century, also the leading engineers and 
technical managers in the US petroleum industry perceived the environmental damages caused by pipeline leaks, blowouts of crude oil and more as an efficiency problem. Wasted crude was equal to wasted money (Gorman, 1999). Managing pollution as an efficiency problem was also adopted in the German and the Swedish pulp and paper industry, whose biggest problem at the time was water pollution. Discharges of fibers into the ambient water indicated great inefficiency, as important prospects for earnings were wasted (Söderholm \& Bergquist, 2012). German pulp and paper industry advanced technology to recycle chemicals, triggered by both public complaints over water pollution as well as cost saving motives (Mutz, 2009).

The notion of 'efficiency' functioned as the guiding principle and promising strategy for managers and engineers in dealing with environmental problems. But although the emissions of pollutants was much lower per produced ton copper, pulp or crude oil in 1920 than it had been in 1890 , the total level of pollution yet continued to increase. The efficiency approach was rather a form of natural resource management based on the belief that nature yielded valuable economic assets that should be used in the most efficient manner (Gorman, 1999). However, when the notion of 'eco-efficiency' became widespread more than a century later as a new business concept to implement sustainable development (Ehrenfled, 2012) it was related to the same ideas of efficiency that had appeared many decades earlier. The rationale behind the eco-efficiency concept, was simply to produce more value with less environmental impact. There exists a number of examples of how polluting firms was challenged to curb its avalanche environmental impact as the second industrial revolution took hold, but indeed, it did not change the course of an unsustainable development in manufacturing industries.

\section{Origins of Green Business}

Business history research has recently shown that in parallel to the growth of manufacturing firms, there were also alternative green businesses active in healthy food and in wind and solar 
energy. Jones (2017a) has shown that from the mid nineteenth century to the early twentieth century Europe and the United States saw the emergence of what can be likened with 'protogreen' industries created by a cohort of unconventional entrepreneurs. Individuals like the American John Harvey Kellogg and the British John Henry Cook laid in the late nineteenthand early twentieth century the foundation for future business in healthy and organic food (Jones, 2007a, Chapter 2.) Also the wind and solar industry originates from entrepreneurial achievement that dates back to the late 1800s. In 1888, the American Charles F. Brush became the first person in the world to use wind to generate electricity. By the further achievements by the Danish physicist Poul la Cour on the technology, wind power for electricity generation came to boom in Denmark already during World War 1. The challenge for the wind and solar energy business to grow and scale was, however, overwhelming as long as coal and later oil remained cheap, especially during the decades after World War II. But as Jones have demonstrated, these early ventures laid the basis for technologies, techniques and ideologies which created the foundation for future green large and global firms, such as Whole Foods Market and Vestas.

Household waste in cities has been a well-known nuisance problem since medieval ages, but with industrialization the amount of waste turned into a large-scale challenge. Jones (2017a) has shown that recycling attracted business entrepreneurs in countries including the US, Denmark, Germany and Hungary already from the nineteenth century. But by the twentieth century with the rise of mass production and mass production, waste became epidemic, especially in modern cities in United States and in Europe. Both municipal and private companies developed to meet the emerging challenges related to the accelerating waste generation, and many of the processes for sorting and recycling waste materials in German cities 1920s, are still used in the global waste industry today (Jones, 2017a, Chapter 4). As further has been demonstrated by Stokes et al. (2013) who covered the business history of waste in Germany and Britain after World War 11, both private and public waste companies played a 
decisive role after the amount of waste exploded during the postwar decades. Besides cleaning up the streets, collecting households waste, private and public companies took early responsibility for recycling. But as argued by Köster (2017) as well as Jones (2017a) the waste business in Germany, Great Britain and the United States developed without having a foundation of environmental belief or great environmental concerns. As in the case of the wind and solar industry, most of these early ventures in the waste and recycling business struggled to achieve profitability without public funds. It was only in the 1960s when environmental considerations began to impact environmental policies towards waste management that it grew into a big, even global business.

\section{Environmental Concerns on Hold}

The first wave of environmentalism that had emerged as a direct reaction to the consequences of the industrial revolution declined in the 1930s. People and governments became occupied by hardships of the Great Depression and World War II and little attention was paid to the effects of a growing population and rapid industrial growth on the natural world and on themselves. After World War II, citizens were absorbed by materialism and a careless optimism on the one hand, and the cold war and the threat of nuclear annihilation on the other (Shabecoff, 2000). Yet new technologies and explosive economic expansion created escalating environmental pressures. As stressed by environmental historians, the postwar period constituted an acceleration of environmental unsustainability compared to previous periods (McNeill \& Engelke, 2014). After 1945, the world economy became driven by enormous quantities of fossil fuels - mostly oil. From the year of 1900, the oil production increased from 20 million tons in to 3 billion tons in 1990 (McNeill, 2000). This was reflected in the growth of number of cars, which increased from around 40 million after 1945 to nearly 700 million by 1996 (Steffen et al. 2007). 
The growth in big business was based on fossil fuels and steel. In 1955, the largest corporations in the US was General Motors, followed by Exxon Mobil, U.S. Steel and General Electric (Fortune 500 database). In the United States, the petroleum industry did not operate free from environmental regulatory constraints, but was not really challenged by them either. Many efforts to increase the efficiency with which companies extracted, transported, and refined petroleum did overlap with efforts to address pollution concerns (Gorman, 2001, 269). Between the end of World War II and the 1960s, the German industry was not under much pressure either. The German legal system formally prioritized economic performance over protection of victims of pollution (Jones \& Lubinski, 2014). Environmental concerns and pressure on industry was also on hold in the Scandinavian countries. In Sweden, who had had a serious parliamentary debate about enforcing an extensive industrial pollution control system in the early 1900s, abounded the initiative in the 1920s (Bergquist \& Lindmark, 2016) and the issue did not return as a serious concern to industry or the government before the $1960 \mathrm{~s}$ (Söderholm \& Bergquist 2012). A first wake-up call that things were getting out of control, at least in Europe, came with the Great Smog in London in 1952. The first European international convention concerning air pollution was held in Milan in 1957 (Bergquist, 2017).

Although the anti-pollution and nature conservation movement became subdued in the 1930s, entrepreneurs in organic food was still active if marginal in countries like Britain, Germany and the United States. In 1959 the retail shop Wholefood, was opened in London. But this particular business and equivalent ventures remained wholly niche. As Jones (2017a) have shown, there were many challenges in developing an organic food business, from how by whom to grow organic food to persuade consumers to buy it and the business remained tiny. Also entrepreneurial startups in "natural beauty"-beauty products based on natural ingredientsdeveloped in the United States and France but remained, as organic food, wholly marginal to the mainstream market. Barber (2016) have moreover shown that solar heating experiments in 
building were undertaken in the United States between 1939 and 1949, but as the war restrictions waned and oil became cheaper, investments in solar heating waned. The corporations and governments around the world were by the 1960s heavily invested in a present and future empowered by oil and there was a rapid loss of sustainability in both the US and the rest of world (Barber, 2016: 205).

A more radical and popular debated started however the US, with the publication of Rachel Carson's book Silent Spring (1962). Carson was a good writer and popularized existing knowledge of the dangers of indiscriminate use of pesticides in agriculture. It was the beginning of an explosion of popular literature reflecting the new scientific knowledge about invisible threats in the environment: radiation, heavy metal waste and other problems. The first mass movement for environmental protection thus started in the United States and focused on domestic issues (Porter \& Brown, 1996) but other countries had their own debates in the 1960s. Political and public concern about air, soil and water pollution started overall to occur in noncommunist industrial countries. In 1967, the OECD established advisory groups for different environmental problems, among them auto exhaust emissions, and environmental impact from sulfur products and detergents. The list of issues that the OECD found urgent, were extended every year after 1967 (Long, 2000). The second wave of environmentalism was on rise.

\section{Business and the Second Wave of Environmentalism}

An extensive academic literature has covered rise of environmentalism in the 1960s and the early 1970s. A complex of many factors came to lay the foundation of the adoption of the sustainability concept in the 1990s. The publication of Silent Spring (1962), the United Nations Conference on the Human Environment held in Stockholm in 1972, the Arab Oil Embargo in 1973 along with publication of the book Limits of Growth (Meadows at al. 1972) by the Club of Rome in 1972 have been widely seen as core formative events. Devastating environmental 
catastrophes caused by corporations in the 1970 s and the 1980 s, most notably the Bhopal catastrophe in 1984 and Exxon Valdez oil spill in 1989, also raised new levels of pressure on business, especially on multinationals. This interplayed with scientific findings regarding the impact of different pollutants causing acid rain, ozone depletion, eutrophication, mercury intoxication, and eventually climate change and a wide range of other issues. There was an outbreak of new NGOs, governmental institutions and national and supranational legislations from the late 1960s and the 1970s, which came to impact business in several ways (Coglianse \& Anderson, 2012: Weber \& Soderstrom, 2012). The impact of this historical shift has only recently been given broader coverage in the business history literature (Jones, 2017a; Berghoff \& Rome, 2017).

\section{Corporate Environmentalism}

The 1960s was a period when corporations started to grow in environmental awareness. In the United States, public attention and criticism was directed towards the US chemical industry, automobile emissions and oil spills. Attention to environmental issues increased in Europe as well, with countries like Sweden pioneering environmental policies (Andersen \& Liefferink, 1997). Japan had its own debate in the 1960s centered on the disaster in Minamata, where mercury emissions from Japan's leading petrochemical manufacturer Chisso Corporation which in the end caused the death of estimated 1,000 Japanese citizens while many more victims came to suffer from being poisoned by mercury (Almeida \& Brewster Stearns, 1998).

The management scholar Andrew J Hoffman's work on the US history of corporate environmentalism has been frequently cited to describe different modes of business responses to the environmental issue from the 1960s. Hoffman identified a movement along an evolutionary adaptive learning process forming specific attitudes or modes of business responses during certain sub-periods. 


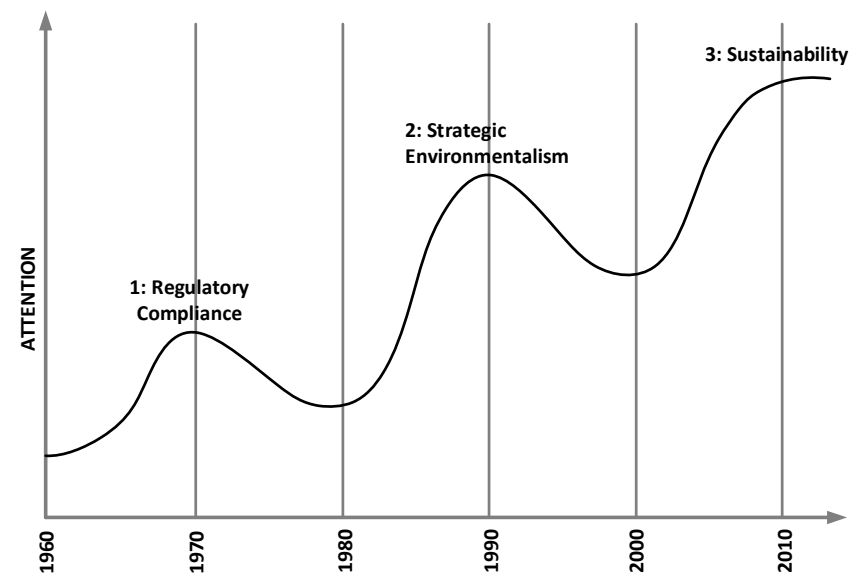

Source: Hoffman \& Bansal (2012) p. 5.

According to Hoffman's and Bansal's periodization (Figure 2) corporate environmentalism in 1960s and the 1970s embraced the recognition that corporate environmental issues as a problem that necessitated regulatory control, and business responded with a strategy of regulatory compliance. In the 1980s and the early 1990s, business adopted a more pro-active and strategic approach, which was a response to, among other things, a number devastating catastrophic events, such as the accidental release of methyl isocyanate gas at a Union Carbide plant in in Bhopal, India, in 1984. A third wave of corporate environmentalism, then came to embrace the concept of sustainability. This shift begun in the latter part of the twenty first century and came to focus on the merger of environmental and social issues with the global economy. The shift was driven by a series of events and issues that had forced on expansion of the scope of environmentalism to include considerations for a restructuring of global economies (Hoffman \& Bansal, 2012: 7-9). The most important issue for business in the third wave was, and still is, climate change.

Hoffman's framework (1997) covering the 1960s to the late 1990s were based on empirical studies of the US chemical and petroleum industry, who responded reactive and 
defensive towards environmental regulations in the 1970s. This view has also been supported by business historical studies such as Archie B. Caroll et al. (2012) who have argued that most American companies were resisting environmental regulations in the 1970s along with delaying investments as long as possible. Only a minor part of the American executives perceived that they had major responsibility towards the natural environment (Carrol at al. 2012: 254-255, Fisher \& Shot, 1993). Results from McCarthy's research on the environment and US car industry also supports this view (McCarthy 2007: 190). In a recent study by Müller (2017) the mercury crisis in the Great Lakes and the prosecutions against Dow Chemical in the early 1970s is examined, and points at the many complexities that was related to an evolving environmental issue, in this case mercury and corporate and legal responses.

Business history research gives no clear and coherent picture of how manufacturing companies did respond to the new complex of environmental issues emerging from the 1960s. The way national polices shaped business strategies to manage growing environmental concerns is likewise uncertain. Boulett (2006) has explored the development of modes of corporate responses to the environmental issues in the French industry 1950-1990 and identified three stages of business behavior; inattention, adaptation and integration. Inattention dominated until the end of the 1950s, but in the 1970s, specific adaptive behaviors are progressively gaining momentum, often as a result from public action. The scope of this initial dynamic was mostly national, but this trend was reinforced after 1979 by external forces, such as European regulation and internationalization. Growing signs of integration into management practices can be found in the second half of the 1980s. Boulett stressed, however, that not all corporations have gone through these stages at the same rate and that the large French corporations adopted various attitudes depending on, among other things, specific geographical contexts.

Jones \& Lubinski (2014) have explored the development of environmental strategies in the German chemical industry in the 1950 s to the 1980 s and found that it diverged from their 
American counterparts in the 1970s by acting proactively and using public relations strategies not only to contain fallout from criticism, but also as opportunities for changes in corporate culture. This reflected not only the broader emergence of environmental issues in German society and government, but also that the pro-active strategy was driven by geographical circumstances. The location of the head offices of the leading firms Bayer and Henkel in the state of North Rhine-Westphalia near the Rhine River meant that senior management was directly exposed to criticism by local activists and regional politicians about polluted water and bad odors, which posed a threat to reputations.

In exploring the development of environmental strategies and clean technology development in the Swedish pulp and paper industry, Bergquist \& Söderholm $(2011 ; 2015)$ stressed the role of environmental regulation, and how different styles of national regulations may lead to different corporate responses to the environmental issue. They argued that in the Swedish case, the co-operative and flexible style in Swedish environmental policies helps to explain why and how Swedish pulp and paper took a world leadership in developing cleaner technologies in the 1970s and the 1980s. Bergquist (2017) have also stressed that the expansion of international regulation from the 1990s, complicated the 'the rules of the game' considerably for the Swedish industry compared to the previous two decades, while the emerging concept of sustainable development provided an opportunity to gain green reputation, even for heavy manufacturing industries.

International business scholars have stressed that the interactions between governmental environmental policy and the strategies of multinationals have been much more complex than equivalent business-government interactions at the national level. From the 1960s, environmental policies diverged across countries, and multinationals have had to comply with different national jurisdictions (Rugman \& Verbeke, 1998). The impact of such complexities has been clearly demonstrated by Jones (2005) history of Unilever between 1965 and 1990. 
Unilever experienced increased environmental pressure already from the 1960s, but remained reactive towards the environmental issue in the 1970s and the 1980s. Its highly diversified nature, handicapped the development of a strong corporate-wide environmental strategy. Another complicating factor was that the company had to struggle with figuring out what to do in different legal jurisdictions and countries with lower level of incomes (Jones, 2005: 342447).

Sluytermann's study of Royal Dutch Shell (Sluytermann, 2010; 2007: 303-365) provides an example of the devastating costs to reputation that followed by the company's inability to meet the social and environmental expectations from its stakeholders. Shell's presence in South Africa, the planned sinking of the Brent Spar in the North Atlantic Sea in the early 1990s along with the environmental and human rights concern in Nigeria, contributed to a situation when Shell's reputation and legitimacy eroded. This resulted in a situation when the company seriously had to rethink the company's ethics, values and co-ordination to be able to meet the complex a sustainability which it faced in order to keep its license to operate.

There is still no comprehensive business history account of how the environmental issue challenged business corporations from the 1960s, although there was a dramatic expansion in the scope, volume and detail of, for instance, environmental law during the past decades (Coglianese \& Andersson, 2012). The dominant research stream in international business literature on sustainable development has also neither focused much on challenges and business responses at the firm level, as the dominant research stream has been of macro-economic and quantitative nature (Van Tulder et al. 2014).

\section{Sustainability as mainstream business}

In the 1990s, capitalism was getting re-defined as an agent capable of meeting the world's needs. This was a big shift from the discourse of the 1970s. A number of different industries, 
even oil and gas, which had been resisting environmental regulations in the 1970s, declared that they now had reached the point when the ongoing degradation of the environment had to be dealt with urgently, including climate change. Sustainability suddenly emerged as something that was compatible with profits and something that could enhance value also in large multinational corporations. Caroll et al. $(2012 ; 349$.) suggested that this happened as the global competition increased in the 1990s, and companies' international images and brand reputation became more vulnerable. In 2000, British Petroleum embarked on a massive 200 million dollar campaign to position itself as a leading environmental and safety company with the slogan 'Beyond Petroleum' (Gendron et al. 2017). Two years later the presidents of DuPont, Anova Holding AG and the Royal Dutch Shell published the book Walking the Talk. The Business Case for Sustainable Development, and argued that they were now more convinced than ever that companies can do themselves good through doing the right for society at large and the environment (Holliday et. al. 2002: 8).

Jones (2017a) has suggested a number of overlapping factors that help to explain why a mainstreaming of sustainability in business happened. First of all, the environmental issue became redefined under the category of sustainability by the Brundtland report in 1987. As the concept of sustainability merged both social issues and economic growth, it was compatible with large corporations. Secondly, the sustainability concepts were made readily adaptable to firms by arguments, definitions, certifications and metrics developed by leaders of green thought such as John Elkington and Paul Hawken (see also Rome, 2017). As a third factor contributing to the mainstreaming of sustainability was the growing market preferences for greener products in the 1990s. Large corporations from food and beauty to energy companies needed to gain value from green reputations. A fourth factor discussed by Jones, was that the business risks that could be facilitated from climate change. One such industry is the reinsurance industry, who has a vested interest in sustainability long-term risks (Haueter \& Jones, 
2017). A fifth factor has to do with a shift in government policies, and new regulatory tools that reduced financial barriers of investing in sustainability, such as renewable energy and organic food. Finally, a sixth factor was related to the new and powerful role of NGOs. The growing numbers of NGOs got increasing opportunities to expose poor environmental practices, but they also provided institutional capacity to enhance big business reputations through partnerships. Corporations could, for instance, use NGOs for product certifications and to form alliances involving matters such as supply chain management (Jones, 2017a, 360-363). One many examples is the Swedish furniture company IKEA who in 2007 partnered with the World Wildlife Fund to support forest managers in countries like Russia and China in sustainably forestry (Strand, 2008).

One striking feature in global business from the 1990s was the megatrend of business self-regulation, or sometimes mentioned as voluntary regulation. This development has been perceived as a reflection the new role played by a various set of stakeholders who expected global firms to take their responsibility for sustainability issues, especially multinational companies due to their enormous power. Costumers, investors, consumers, NGOs and other stakeholders expected not only words but also 'proof'. Large corporations begun in the 1990s issuing sustainability reports alongside their business reports (Berghoff, 2017). An array of codes, standards, guidelines and frameworks were developed to guide companies in integrating sustainability and corporate social responsibility into their business strategies and management processes. The development was explosive, and more than 300 global corporate standards could be identified in the early 2000 , each with its own history and criteria (Marion et al. 2012). In 1996, the International Organization for Standardization (ISO), the Genevabased international body of national standards institutions, launched the Environmental management system ISO 14001. In 2002, the ISO 14001 had already been adopted by nearly 50,000 facilities in 118 countries (Prakash \& Potoski, 2006: 25). 
Another matrix, the Global Report Index (GRI) was created in 1997 under the initiative of the non-profit organization North American Coalition for Environmentally Sustainable Economies (CERES), with the United Nations Environmental Program as a joint partner from 1999. The Tripple Bottom Line concept, which had been launched by John Eklington (1997) in the early 1990s, laid the foundation for Global Reporting Initiative (GRI), a framework for principles for environmental, social and sustainability reporting (Grey \& Harremans, 2012: 410; Jones 2017a). The purpose of the GRI was to enable the diffusion of sustainability records and to provide information guidelines to present a clearer vision of the human and ecological impacts, not the least from large enterprises (Marimon et al., 2012). During the first year (1999) 12 large corporations joined the GRI, among them the US based General Motors, Procter \& Gamble and Acea, the UK based British Airways the Japanese Panasonic Corporation and the Swedish SCA and Electrolux. The 12 number of firms that had been listed in 1999, had increased to over 6000 in 2016 (GRI Database, 2017).

Jones (2017a) has explored the origins and growth of these new "green institutions", such as green certification which came to lay the foundation of the expansion of green business markets, from organic food, green building to eco-tourism to natural beauty and other sectors. The aim with certification was essentially to define what sustainability was in different such as contexts. Jones showed that even though certification has been fundamental to the creation and expansion of green markets, the creation of certifications and new accounting principles also provided metrics that enabled big business to demonstrate publicity that it was becoming sustainable. Certification, environmental reporting and green washing also made the boundaries of the concept of sustainability so wide that any corporation could be engaged in it (Jones, 2017a: 233-262, 379).

Scholars in international business have also stressed that concerns remain whether certifications to environmental standards are accurate signals of firms' environmental conduct, 
and that future research should pay much more attention to firm's implementation of international standards and actual outcome especially in a global context. The literature covering the impact and outcomes of sustainability on multinational corporations is still scarce (Christmann \& Taylor, 2012; Van Tulder et al. 2014) and it is difficult to conclude to what degree this global trend have delivered the results that stakeholders have expected. It also appears as if the trend has mostly concerned multinational companies based in Western countries. A recent overview covering the business history of emerging markets (Austin et al. 2017) gives no evidence that the same mainstreaming of sustainability happened in large corporations based in Latin America or in Asia.

\section{The Scaling of Green Business}

Climate change and other issues of sustainability will require, as it has been stated, a future 'green growth' transition that needs to be large, system-wide and structural, in other words, a new industrial revolution based on renewable energy (Bowen et al. 2016). Business history research have pointed at the historical circumstances that has prevented growth in the renewable energy industry, and perhaps even more importantly, it has pointed at what kind of factors that has supported its expansion.

Jones (2017a, 2017b) research on the origin and stepwise scaling of wind and the solar industry has contributed with important insights about several important factors that obstructed its growth over the past century. The history of the wind and solar power companies shows in its essence the great difficulties that entrepreneurs faced in raising the amount of capital needed to finance innovation and compete with fossil fuels and nuclear energy before the 1980s. The reason why the world has seen a considerable growth in the solar and wind industry, as well as in the waste-to-energy and recycling business, is the crucial policy shift which emerged among some governments in the 1980s. Jones demonstrates clearly how 
subsidies and tax incentives helped companies to compete with fossil fuels, as they could afford innovation and, more importantly to scale up their businesses. Thus Jones (2017a) argued that clustering of the wind power industry in Denmark can largely be explained by a functioning governmental policy to support its growth. Likewise, the fluctuating public polices in the United States helps to explain why the leadership in wind and solar technologies faltered, giving the opportunity for Europe and then China to take a leadership position.

The business of organic food and drink, also explored by Jones (2017a: 2018), has expanded from being marginal small businesses in the 1980s into a global industry in the 2000s. The market growth in consumption of organic food as well as organic agriculture shows, however, wide geographical variations. In the United States, organic food production expanded from the 1980s in California, while in Europe it was most evident in Germany, Switzerland and Denmark. The German organic wholesaler Rapunzel started in the mid-1980s a long-term organic farming project in Izmir, Turkey, and the company eventually developed a purchasing network in some thirty countries. Meanwhile in Egypt, Ibrahim Abouleish created Sekem with business spanning from biodynamic farming, organic cotton and investments in schools. However, as Jones has shown, there was also an increasingly divorce between production and consumption of organic food from the 1980s, as production globalized. This raised new environmental concerns about long-distant trade, which raised the carbon footprint of the industry. The American-based Whole Foods Market, founded in 1980, came to source organic food on industrial scale from different parts of the world as the company scaled in the US market. The largest regional source of organic food production was in 2014 located in Australia and the Pacific Islands (Jones, 2017a:176-201), while the major organic tea growing nations were found in South Asia, East Africa and China (Jones, 2018) Clustering was, however, as Jones (2017a; 2018) has noted, not confined organic food and drinks. In the Latin America for 
example, a cluster of local brands in natural beauty emerged in Brazil, while a big cluster of eco-tourism developed in Costa Rica.

The creation of certification and eco-labelling has been identified as instrumental for the market expansion of organic food products (Broberg, 2010) but also for other green industries (Jones, 2017a). In contrast, a failures to establish a clear, nationally accepted standard subdued the growth of organic food markets and organic agricultural output, as has been demonstrated in Jones' and Mowatt's (2016) study of the slow growth of the organic food business in New Zeeland. Failures to establish a cohesive and accepted certification for organic wine, also discouraged conventional winemakers from entering the organic industry (Jones, 2018).

One of the more unsustainable global industries with a considerable growth in recent decades is international tourism. From the 1980s it has expanded from 200 million international tourist arrivals to more than one billion arrivals each year since 2010 and exerts an enormous pressure on the environment (Mowforth \& Munt, 2015). Business history research has covered how eco-tourism has emerged as on important alternative business sector from the 1990s (Jones, 2017a). Although the growth of the eco-tourism industry in countries like Costa Rica grew while enhancing sustainability in terms of saving the countries rainforests and improving biodiversity, it also became threatened by green-washing. The problem with green washing soon emerged as business which were not environmentally sustainable sought to take advantage to free ride on the national image that had been created (Jones and Sadafora, 2017). The formalization of the concept of eco-tourism was also accompanied by growth of its customer base far beyond ecologically committed consumers. Once the global eco-tourism market had been proven, conventional firms sought to enter the business segment (Jones, 2017a). 
The threat of green-washing in the eco-tourism business represents a general problem in the scaling of green business. When conventional industries entered the field, it involved a complex of problems around green washing and social constructions of sustainability as business sought to give their brands a greener image. As has been shown by Jones (2017a) large conventional corporations started to acquire visionary green firms in the 1990s, in order to associate their brands with environmental and social responsibility.

The growth of environmental awareness in business and among research scholars on this phenomenon has not resulted in a decline in global environmental challenges, in fact the opposite. Quarterly capitalism developing from the 1980s is not aligned with the long-term investments horizons needed for green business (Jones, 2017a).

\section{Conclusions}

Fossil fuel laid the foundation of Western industrial capitalism and its success. The creation of modern capitalism and big business was essentially the story of manufacturing firms growing large by employing enormous amounts of fossil fuels. Business historians have spent generations exploring that that story, and why some countries and firms proved more successful than others in building capitalist enterprise. However, today's debates around sustainability are about moving beyond this past focus. There now exists, after a lag, a growing stream of research on the environmental consequences of capitalist growth.

This new research has two dimensions. The earliest theme to be explored, in a literature dating from the 1990s, is the story of when, how and why some conventional industries sought to become less polluting. This stream of research has dated this phenomenon back to the late nineteenth century, showed that it gained momentum and complexity from the 1960s, and resulted in a mainstreaming of sustainability rhetoric, and sometimes practice, in large corporations from 1980s, primarily in Western developed countries. Scholars have explored 
business responses to a wide set of environmental issues, including public pressure, environmental regulations and technological challenges, in both different industries and geographical contexts.

A more recent stream of research is the story of how for-profit entrepreneurs developed new product categories such as organic food, and wind and solar energy, which were explicitly focused on sustainability. Again this process has been traced back to the nineteenth century. It has again been explored in different industries and geographies, and it has been shown to have laid the technological and intellectual basis for a range of today's green businesses, even if these early green entrepreneurs were rarely able to build scalable businesses before the 1980s.

With the rise in green consumerism and public policy support in some Western countries for sustainability during the 1990s, the two historical trends identified above met, as the concept of sustainable development spread to large conventional corporations and visionary green firms scaled or were acquired by conventional big businesses. A new constraint in business sustainability emerged as the very concept of sustainability became socially constructed in a sufficiently broad fashion as to permit even firms in the most unstainable and dirty industries to be certified and win awards for being sustainable.

The issue of sustainability and green business has received attention in management research, as well as in economics, with a growing number of subfields and journals devoted to the issue. The emerging business history research needs to be more fully incorporated in the debates in these literatures. Subfields within science have also become increasingly focused on the historical dynamics of capitalism, centered on the Great Acceleration and Anthropocene debates, which has engaged scholarly work by environmental historians. Today no other issue dominates the concerns about sustainability more than climate change, and the issue cuts across not only virtually all industries but also the whole global economy. It is now a matter of urgency to make sustainability a mainstream topic in business history. 


\section{References}

Aggeri, Franck and Cartel, Melodie (2017), 'Le Changement Climatique et les Entreprises: Enjeux, Espaces d'action, Régulations Internationales', Entreprises et Historie, 1 (86), 6-20.

Almeida, Paul and Brewster Stearns, Linda. (1998), 'Political Opportunities and Local Grassroots Environmental Movements: The Case of Minamata', Social Problems, 45 (1), 37-60.

Andersen, Mikael Skou and Liefferink, Duncan. (eds.) (1997), European Environmental Policy:

The Pioneers (Manchester: Manchester University Press).

Austin, Gareth, Jones, Dávila, Carlos and Jones, Geoffrey (2017), 'The Alternative Business

History; Business in Emerging Markets', Business History Review, doi: $10.1017 / \mathrm{S} 0007680517001052$

Barber, Daniel A. (2016), A House in the Sun. Modern Architecture and Solar Energy in the Cold War (New York: Oxford University Press).

Berghoff, Hartmut and Adam. Rome (eds.) (2017), Green Capitalism? Business and the Environment in the Twentieth Century (Philadelphia: University of Pennsylvania Press).

Berghoff, Hartmut (2017), 'Shades of Green: A Business-History Perspective on Eco-Capitalism', in Berghoff, Hartmut and Rome Adam (eds.), Green Capitalism? Business and the Environment in the Twentieth Century (Philadelphia: University of Pennsylvania Press), 13-31.

Bergquist, Ann-Kristin (2017), 'Dilemmas of Going Green: Environmental Strategies in the Swedish Mining Company Boliden 1960-2000' in Berghoff, Hartmut and Rome Adam (eds.) Green Capitalism? Business and the Environment in the Twentieth Century' (Philadelphia: University of Pennsylvania Press) 149-171.

Bergquist, Ann-Kristin and Lindmark, Magnus (2016), 'Sustainability and Shared Value in the Interwar Swedish Copper Industry', Business History Review, 90 (2), 197-225. 
Bergquist, Ann-Kristin and Söderholm, Kristina (2015), 'Transition to Greener Pulp: Regulation, Industry Responses and Path Dependency’, Business History, 57 (6), 862-884.

Bergquist, Ann-Kristin and Söderholm, Kristina (2011) 'Green Innovation Systems in Swedish Industry, 1960-1989’, Business History Review, 54 (4), 677-698.

Blackford, Mansel G. (2012), Making Seafood Sustainable. The American Experience in a Global Perspective (Philadelphia: University of Pennsylvania Press).

Blowfield, Michael (2013), Business and Sustainability (Oxford, Oxford University Press).

Brenton, Tony (1994), The Greening of Machiavelli: The Evolution of International Environmental Politics (London: Earthscan Publication Ltd).

Broberg, Oscar (2010), 'Labeling the Good: Alternative Visions and Organic Branding in Sweden in the Late Twentieth Century', Enterprise \& Society, 11 (4), 811-838.

Boulett, Daniel (2006) 'La Gestion De L'environnement Dans Les Entreprises Industrielles en Face : Une Mise En Perspective Historique', (1950-1990), Entreprises et Historie 45, 54-73.

Bowen, Alex, Duffy, Chris and Fankhauser, Sam (2016), 'Green Growth and The New Industrial Revolution', Policy brief, London School of Economics and Political Science.

Carroll, Archie B., Lipartito, Kenneth J., Post, James E. and Werhane Patricia H. (2012), Corporate Responsibility: The American Experience (Cambridge: Cambridge University Press).

Carson, Rachel (1962), Silent Spring (Boston: Houghton Mifflin).

Chandler, Alfred D., Amatori, Franco and Hikono, Takashi (1997), Big Business and the Wealth of Nations. (Cambridge; New York: Cambridge University Press).

Chandler, Alfred D. (1990), Scale and Scope: The Dynamics of Industrial Capitalism (The Belknap Press of Harvard University Press). 
Christmann, Petra and Taylor Glen (2012), 'International Business and The Environment' in Pratima Bansal and Hoffman, Andrew J (eds.), The Oxford Handbook of Business and the Natural (Oxford; New York: Oxford University Press), 50-69.

Clark, Gregory (2004), A Farewell to Alms: A Brief Economic History of the World (Princeton: Princeton University Press).

Coglianse, Cary and Anderson, Ryan (2012), 'Business and Environmental Law' in Pratima Bansal and Hoffman, Andrew J (eds.), The Oxford Handbook of Business and the Natural Environment (Oxford; New York: Oxford University Press), 140-157.

Cohen, Stewart, Demeritt, David, Robinson, Johan, Rothman, Dale (1998), 'Climate Change and Sustainable Development: Towards Dialogue', Global Environmental Change, 8 (4): 341-371. Cronon, William (1991), Nature's Metropolis: Chicago and the Great West (New York: W.W Norton).

Ehrenfled, John R. (2012), 'Beyond the Brave New World: Business and Sustainability', in Pratima Bansal and Hoffman, Andrew J (eds.), The Oxford Handbook of Business and the Natural Environment (Oxford; New York: Oxford University Press), 611-629.

Elkington, John .B. (1997), Cannibals with Forks; The Triple Bottom Line of 21st Century Business (Oxford: Capstone Pub.).

Friedman, Walter and Jones, Geoffrey (2011), 'Business History. Time for Debate. Business History Review, 85 (1), 1-8.

Gendron, Corinne, Girard, Bernard., Ivanaj, Silvester., Ivanaj, Vera., and Friser, Alice. (2017), 'Rôle et responsabilités des hauts dirigeants face aux changements climatiques: réflexions à partir du cas e BP', Entreprises et Historie, 1 (86): 34-53.

Gorman, Hugh. S. (2001), Redefining Efficiency. Pollution Concerns, Regulatory Mechanisms and Technological Change in the US Petroleum industry (Akron: University of Akron Press) 
Gorman, Hugh. S (1999), 'Efficiency, Environmental Quality, and Oil Filed Brines: The Success and Failure of Pollution Control Self-Regulation', Business History Review, 73 (4), 601-640.

Gray, Rob and Herremans, Irene (2012), 'Sustainability and Social Reporting and the Emergence of the External Social Audits: The Struggle of Accountability?' in Pratima Bansal and Hoffman, Andrew J (eds.), The Oxford Handbook of Business and the Natural Environment, (Oxford; New York: Oxford University Press), 140-157.

Guha, Ramachandra (2000), Enviornmentalism: A Global History (New York: Longman).

Gunningham, Neil., Kagan, Robert A. and Thorthon, Dorothy (2003), Shades of Green. Business, Regulation, and Environment (Stanford, Calif: Standford Law and Politics)

Haueter, Neils Viggo and Jones, Geoffrey (2017), Risk in Reinsurance. Managing Risk in Reinsurance. From City Fires to Global Warming (Oxford: Oxford University Press).

Hoffman, Andrew. J \& Bansal, Pratima (2012), "Retroperspective, Perspective and Prospective: Introduction" in Pratima Bansal and Hoffman, Andrew J (eds.), The Oxford Handbook of Business and the Natural Environment (Oxford: New York: Oxford University Press), 140-157.

Hoffman, Andrew J. (1997), From Heresy to dogma. An institutional History of Corporate Environmentalism, (San Francisco: The New Lexington Press).

Holliday, Charles O. Jr., Schmidheiny, Stephan and Watts, Philip (2002), Walking the Talk: The Business Case of Sustainable Development (Sheffield: Greenleaf).

Institute for Sustainable Development (2012). "Sustainable Development Timeline". https://www.iisd.org/pdf/2012/sd timeline 2012.pdf

Jones, Geoffrey (2018), Varieties of Green Business: Industries, Nations and Time (Northampton, MA: Edward Elgar)

Jones, Geoffrey (2017a), Profits and Sustainability. A Global History of Green Entrepreneurship (Oxford: Oxford University Press). 
Jones, Geoffrey (2017b), 'Entrepreneurship, Policy and Geography of Wind Energy', in Berghoff, Hartmut and Rome Adam (eds.), Green Capitalism? Business and the Environment in the Twentieth Century' (Philadelphia: University of Pennsylvania Press), 206-231

Jones, Geoffrey and Spadafora, Andrew (2017), 'Creating Ecotourism in Costa Rica, 1970-2000', Enterprise \& Society, 18(1), 146-183.

Jones, Geoffrey and Mowatt, Simon (2016), 'National Image as a Competitive Disadvantage: the case of the New Zealand Organic Food Industry', Business History, 58 (8), 1262-1288.

Jones, Geoffrey and Lubinski, Christina (2014), 'Making 'Green Giants': Environment Sustainability in the German Chemical Industry 1950s-1980s'. Business History, 56 (4): 623 649.

Jones, Geoffrey and Jonathan Zeitlin (2008), The Oxford Handbok of Business History (Oxford: Oxford University Press).

Jones, Geoffrey (2008), 'Globalization' in Jones, Geoffrey and Jonathan Zeitlin (eds.), The Oxford Handbok of Business History (Oxford: Oxford University Press).

Jones, Geoffrey (2005), Renewing Unilever: Transformation and Tradition (Oxford; New York: Oxford University Press).

LeCain, Timothy. J. (2009), Mass Destruction: The Men and Giant Mines That Wired America and Scarred the Planet (New Brunswick, N.J: Rutgers University Press).

LeCain, Timothy. J. (2000), 'The Limits of "Eco-Efficiency”: Arsenic Pollution and the Cottrell Precipitator in the U.S. Copper Smelting Industry', Environmental History, 5(3), 336-351.

Lindmark, Magnus and Bergquist, Ann-Kristin (2009), 'Expansion for pollution reduction? Environmental adaptation of a Swedish and a Canadian Metal Smelter 1960-2005', Business History, 50 (4), 530-546.

Long, Bill L. (2000), International Environmental Issues and the OECD 1950-2000 (Paris: OECD Publishing). 
MacMillan, Donald (2000), Smoke Wars: Anaconda Copper, Montana Air Pollution, and the Courts, 1890-1924 (Helena, Mont.: Montana Historical Society Press)

Marimon, F. Frederic, Alonso-Almeida, Maria Del Mar, Rodriguez, Martha Del Pila, Alejandro, Cortez and Aimer, Klender (2012), 'The World Wide Diffusion of Global Reporting Initiative: What is the Point?', Journal of Cleaner Production, 33, 132-144.

Maysilles, Duncan (2011), Ducktown Smoke: The Fight over One of the South's Greatest Environmental Disasters (Chapel Hill: University of North California Press).

McNeill, John R. (2000), Something New Under the Sun: An Environmental History of the Twentieth-Century World (New York: W. W. Norton).

McNeill, John R. and Engelke, Peter (2014), The Great Acceleration. An Environment History of the Anthropocene since 1945 (Cambridge, Massachusetts: The Belknap Press of Harvard University Press).

McCarthy, Tom (2007), Auto Mania. Cars, Consumers, and the Environment (New Haven: Yale University Press).

Meadows, Donella H., Meadows, Dennis, L., Randers, Jergen and Behrens, William .W. (1972), The limits to growth. (New York: Universe Books)

Mowforth, Martin and Munt, Ian (2015), Tourism and Sustainability. Development, globalization and new tourism in the third world (Abingdon, Oxon: Routledge)

Mutz, Mattias (2009), 'Managing Resources: Water and Wood in the German Pulp And Paper Industry 1870s-1930s', Jahrbuch für Wirtshaftsgeschiticthe/Economic History, Yearbook 59 (2), 45-68.

Newell, Edmund (1997), 'Atmospheric Pollution and the British Copper Industry, 1960-1920', Technology and Culture, 38 (3), 655-689. 
Prakash, Aseem and Potoski, Matthew (2006), The Voluntary Environmentalists: Green Clubs, ISO 14001 and Voluntary Environmental Regulations (Cambridge: Cambridge University Press).

Pomeranz, Kenneth (2000), The Great Divergence. China, Europe, and the Making of the Modern World Economy. (Princeton: Princeton University Press).

Porter, Gareth and Brown, Janet Welsh (1996), Global Environmental Politics, Second Edition (Boulder, Colorado: Westview Press).

Post, James E. (2012), 'Business, Society and the Environment', in Pratima Bansal and Hoffman, Andrew J (eds.), The Oxford Handbook of Business and the Natural Environment (Oxford: New York: Oxford University Press), 537-555.

Robinson, John (2004), 'Squaring the circle? Some thoughts on the idea of sustainable development', Ecological Economics 48, 369-384.

Rome, Adam, (2017), 'The Ecology of Commerce: Environmental History and the Challenge of Building a Sustainable Economy', in Berghoff, Hartmut and Rome, Adam (eds.), Green Capitalism? Business and the Environment in the Twentieth Century' (Philadelphia: University of Pennsylvania Press), 13-31.

Rootes, Christopher (2004), 'Environmental Movements in Snow, David A., Soule, Sarah, A. and Kriesi, Hanspeter (eds.), The Blackwell Champion to Social Movements (Malden, Mass.: Blackwell)

Rosen, Christine Meisner (2017), 'Business Leadership in the Movement to Regulate Industrial Air Pollution in Late Nineteenth- and Early Twentieth-Century America' in Berghoff, Hartmut and Rome Adam (eds.), Green Capitalism? Business and the Environment in the Twentieth Century (Philadelphia: University of Pennsylvania Press), 53-76.

Rosen, Christine Meisner (2003), ' Knowing' Industrial Pollution: Nuisance Law and the Power of Tradition in a Time of rapid Economic Change, 1840-1864', Environmental History 8(4), 
656-597.

Rosen, Christine Meisner and Sellers, Christopher C. (1999), 'The Nature of the Firm: Towards an Ecocultural History of Business', Business History Review, 73 (4), 577-600.

Rosen, Christine Meisner (1995), 'Businessmen Against Pollution in Late Nineteenth Century Chicago,' Business History Review, 69 (3), 351-397.

Rugman, Alan M. and Verbeke, Alain (1998), 'Corporate Strategies and Environmental Regulations: an Organizing Framework', Strategic Management Journal, 19 (4), 363-375.

Shabecoff. Philip (2000), Earth Rising. American Environmentalism in the $21^{\text {st }}$ Century (Washington: Island Press)

Sluyterman, Keetie. (2010), 'Royal Dutch Shell: Company Strategies for Dealing with Environmental Issues', Business History Review, 84 (2), 203-226.

Sluyterman, Keetie (2007), Keeping Competitive in Turbulent Markets, 1973-2007. A History of Royal Deutch Shell, Vol 3. (Oxford: Oxford University Press).

Steffen, Will. et al. (2015) 'Planetary boundaries: Guiding human development on a changing planet', Science 347, 6223.

Steffen, Will, Crutzen, Paul J. and McNeill, John R. (2007), 'The Anthropocene: Are Humans Now Overwhelming the Great Forces of Nature?', Ambio, 36 (8), 614-621.

Strand, Robert (2009) 'Corporate Responsibility in Scandinavian Supply Chains', Journal of Business Ethics, 85, 179-185.

Söderholm, Kristina and Bergquist, Ann-Kristin (2012), 'Firm Collaboration and Environmental Adaptation. The case of the Swedish Pulp and Paper Industry 1900-1990, Scandinavian Economic History Review, 60 (2), 183-211.

Ueköetter, Frank (1999), 'Divergent Responses to Identical Problems: Businessmen and the Smoke Nuisance in Germany and the United States', Business History Review, 73, 641-76. Uekötter, Frank (2009), The Age of Smoke. Environmental Policy in Germany and the United 
States, 1880-1970 (Pittsburgh: University of Pittsburgh Press).

Van Tulder, Rob, Verbeke, Alain, Strange, Roger (2014), ‘Taking Stock of Complexity: In Search Of New Pathways to Sustainable Development' in Van Tulder, Rob, Verbeke, Alain, Strange, Roger (eds.), International Business and Sustainable Development (Bingley: Emerald), 1-20. Weber, Klaus and Soderstrom, Sara B. (2012), 'Social Movements, Business and the Environment' in Pratima Bansal and Hoffman, Andrew J (eds.), The Oxford Handbook of Business and the Natural Environment (Oxford; New York: Oxford University Press), 248-265. Whiteman, Gail, Walker, Brian and Perego, Paolo (2013), 'Planetary Boundaries: Ecological Foundations for Corporate Sustainability', Journal of Management Studies, 50 (2), 307-336.

World Commission on Environment and Development (WCED) (1987), Our Common Future (Oxford: Oxford University Press).

World Economic Forum (2016), The Global Risks Report 2016, 11th Edition.

Worster, Donald (1979), Dust Bowl: the Southern Plains in the 1930s (New York: Oxford University Press).

Wright, Christopher and Nyberg, Daniel (2015), Climate Change, Capitalism, and Corporations. Processes of Creative Self-Destruction (Cambridge: Cambridge University Press). 